\title{
КОНЦЕПТЫ “КОЛОНИАЛИЗМ” И “АНТИКОЛОНИАЛИЗМ” В ОЦЕНКАХ ИНТЕЛЛЕКТУАЛЬНОГО НАСЛЕДИЯ КНЯЗЯ Э.Э. УХТОМСКОГО (1861-1921)
}

\author{
Andrey AȘiHMiNa
}

\begin{abstract}
Аннотация
Статья посвящена интерпретации деятельности и интеллектуального наследия известного ориенталиста, публициста и камер-юнкера императорского двора князя Э.Э. Ухтомского в рамках колониального и антиколониального подходов. В тексте производится попытка рассмотреть феномен “восточничества" в русской общественной мысли конца XIX - начала XX вв. На основе документальных материалов Российского государственного исторического архива и Государственного архива Российской Федерации, а также новейшей историографии вопроса автор встраивает "восточничество" в интеллектуальный контекст эпохи и определяет границы данного общественно-политического мировоззрения между колониальным и антиколониальным дискурсами. Во избежание разрозненного представления о столь часто употребляемых в историографии гуманитарных наук терминах “колониализм" и “антиколониализм" автор даёт им собственные определения, в рамках которых и производится анализ биографического, научного и литературного нарративов. Методологический аппарат работы охватывает подходы интеллектуальной истории, биографики и собственно классические практики источниковедческой критики. С помощью анализа ранних юношеских рукописей князя Э.Э. Ухтомского и изучения “мифа морского путешествия", бытовавшего в семье князей Ухтомских, автор пытается обозначить истоки мировоззренческих установок будущего востоковеда и публициста. Отдельный сюжет "Николай II и князь Э.Э. Ухтомский” исследуется в свете имеющейся в личном фонде князя корреспонденции (РГИА. Ф. 1072). Среди основных выводов мысль о том, что невозможно с точностью определить тяготеющее к возвышению азиатской культуры мировоззрение князя как однозначно антиколониальное, поскольку сам Э.Э. Ухтомский как интеллектуал не мог отстраниться от главного мифа, цементирующего европейский цивилизационный ландшафт - идеи об интеллектуальном, политическом и экономическом превосходстве “белого человека" над остальным миром. Транслировав противоположный по смыслу дискурс в своих сочинениях, Э.Э. Ухтомский не убедил императора и общественность в истинности своей концепции. Охлаждение отношений между главным идеологом "восточничества" и монархом в начале 1900-х гг. и последующая Русско-японская война только закрепили при дворе экзотический статус "азиатских причуд”, до конца дней монархии проявлявшийся в тесном взаимодействии императорской семьи с тибетским лекарем П.А. Бадмаевым.
\end{abstract}

a Dr., Russian State Historical Archive, St. Petersburg/Russia, katelive.11@gmail.com 
Ключевые слова: История России, Э.Э. Ухтомский, Николай II, “восточничество”, колониализм, антиколониализм, путешествие на Восток.

$$
\text { 旅濯 }
$$

\title{
THE CONCEPTS OF “COLONIALISM” AND “ANTI-COLONIALISM” IN ASSESSMENTS OF THE INTELLECTUAL HERITAGE OF PRINCE E.E UKHTOMSKIY (1861-1921)
}

\begin{abstract}
The article is devoted to the interpretation of the activities and intellectual heritage of the famous orientalist, publicist and valet de chambre of the imperial court - prince E.E. Ukhtomskiy - within the framework of the colonial and anti-colonial approaches. The text makes an attempt to consider the phenomenon of "orientalism" in Russian public opinion at the end of the XIXth - beginning of the XXth centuries. On the basis of documentary materials from the Russian State Historical Archives and the State Archives of the Russian Federation, as well as the latest historiography of the issue, the author embeds "orientalism" into the intellectual context of the timeline and defines the borders of this socio-political opinion between "colonial" and "anti-colonial" discourses. In order to avoid a scattered understanding of the terms "colonialism" and "anti-colonialism" so often mentioned in the historiography of the humanities, the author gives them his own definitions, within which the analysis of biographical, scientific and literary narratives is carried out. The methodology of the work covers the approaches of intellectual history, biography, and the classical practice of source criticism. By analyzing the early youth manuscripts of Prince E.E. Ukhtomskiy and the study of the "sea voyage myth" of the family of the Ukhtomskiy princes, the author tries to identify the origins of the ideological attitudes of the future orientalist and publicist. A separate plot "Nicholas II and Prince E.E. Ukhtomskiy" is investigated in context of the correspondence, available in the personal found of the prince (RSHA. F. 1072). Among the main conclusions the idea that it is impossible to accurately determine the prince's view tending to the rise of Asian culture as unambiguously "anti-colonial", since E.E. Ukhtomskiy as an intellectual could not move away from the main myth cementing the European civilizational landscape - the idea of the intellectual, political, economic superiority of the "white man" over the rest of the world. Transmitting an opposite discourse in his writings, Ukhtomskiy failed to convince the emperor and the public of the truth of his studies. The cooling in relationship between the main ideologist of "orientalism" and the monarch in 1900 and the Russo-Japanese War only consolidated the exotic status of "Asian fads" at court, which until the end of the days of the monarchy manifested itself in close interaction of the imperial family with the Tibetan doctor P.A. Badmaev.
\end{abstract}

Keywords: History of Russia, E.E. Ukhtomskiy, Nicholas II, "orientalism", colonialism, anticolonialism, a journey to the East.

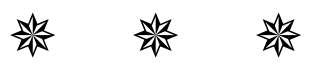

\section{KNYAZ E.E. UHTOMSKIY'İN FİKRÎ MİRASI DEĞERLENDİRMELERINNDE "SÖMÜRGECiLİK" VE "SÖMÜRGECILIIK KARŞITI" KAVRAMLAR (1861-1921)}

$\ddot{\mathbf{O z}}$

Bu makalede, ünlü şarkiyatçı, muharrir ve imparator hizmetinde bulunan (kamer yunker) 
Knyaz E. E. Uhtomskiy'in faaliyetleri ve onun fikrî mirasının kolonyalizm/sömürgecilik ve antikolonyalizm/sömürgecilik karşıtı yaklaşımlar çerçevesindeki izahı ele alınmaktadır. Metin, XIX. yüzyılın sonu ve XX. yüzyılın başlarında Rus toplum hafızasındaki "Doğuculuk/Doğu politikası" olgusunu değerlendirmeye çalışmaktadır. Yazar, Rusya Devlet Tarih Arşivi ve Rusya Federasyonu Devlet Arşivi belgeleri ve bunların yanı sıra konuyla ilgili modern tarih yazımı temelinde, "Doğuculuk/Doğu politikası"nı dönemin entelektüel çerçevesine oturtuyor ve bu sosyo-politik dünya görüşünün sınırlarını sömürgecilik ve sömürgecilik karşıtı söylemler arasında tanımlıyor. Beşeri bilimler tarihyazımında sıklıkla kullanılan "sömürgecilik" ve "sömürgecilik karşıtı" terimlerin farklı anlaşılmasından kaçınmak için yazar, onlara biyografik, bilimsel ve edebi anlatıların analizinin yapıldığı kendi tanımlarını vermektedir. Çalışmanın metodolojisi, entelektüel tarih, düşünce tarihi, biyografi ve klasik kaynak eleştirisi yaklaşımlarını kapsamaktadır. Yazar, E. E. Uhtomskiy'in çocukluk el yazmalarını ve Uhtomskiy sülalesinde var olan “deniz seyahati efsanesi”ni analiz ederek geleceğin şarkiyatçısı ve muharirinin dünya görüşünün kökenlerini belirlemeye çalışmaktadır. "II. Nikolay ve Knyaz Uhtomskiy" adlı müstakil konu knyazın şahsi fonunda (RGİA. F. 1072) bulunan yazışmalar ışığında incelenmiştir. Uhtomsky'in Asya kültürünün yükselişine yönelik dünya görüşünü kesin bir şekilde sömürgecilik karşıtı olarak tanımlamanın imkânsız olduğu fikri, elde edilen esas sonuçlar arasında yer almaktadır. Buna binaen, bilge bir kişilik olmasına rağmen Uhtomsky, dünyanın geri kalanı üzerinde entelektüel, politik ve ekonomik üstünlüğün "beyaz adam"da olduğu yönündeki Avrupa uygarlık söylemini temellendiren kült efsaneden kurtulamamıştır. Yazılarında çelişkili bir söylem takınan Uhtomskiy, imparatoru ve halkı kendi algısının gerçekliğine ikna edememiştir. 1900’lü yılların başlarında "Doğuculuk/Doğu politikası"nın ana ideoloğu ile monarşi arasındaki soğukluk ve akabindeki Rus-Japon Savaşı, imparatorluk ailesinin, monarşi günlerinin sonuna kadar Tibetli Hekim P. A. Badmayev ile yakın ilişkilerinde kendini göstermek kaydıyla "Asya heveslerinin" egzotik statüsünü sağlamlaştırmaktan öteye geçemedi.

Anahtar kelimeler: Rusya tarihi, E.E. Uhtomskiy, II. Nikolay, "Doğuculuk”, kolonyalizm, antikolonyalizm, Doğu'ya yolculuk.

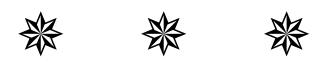

\section{Введение}

В современной историографии русской истории конца XIX - начала XX вB. особенно актуальным является направление интеллектуальной истории и истории идей, в частности - вопросы формирования мировоззренческих установок государственных деятелей и их влияния на политику империи. ${ }^{1}$ В рамках обозначенного подхода перед исследователем стоит задача понять собственно мировоззрение носителя тех или иных культур, идей, убеждений через призму биографики и социокультурного фона, отстранившись от тенденциозного восприятия источников с помощью инструментария герменевтической критики.

В этом смысле интереснейшим феноменом указанного периода является

${ }^{1}$ C 2001 г. в России действует Российское общество интеллектуальной истории, президентом которого является член-корреспондент РАН, известный медиевист Лорина Петровна Репина. Инструментарию и методологическим основам данного направления посвящена её статья: L.P. Repina, “Intellektual'naya istoriya na rubezhe XX-XXI vekov", Novaya i noveyshaya istoriya, № 1 (2006): 12-22. 
творчество князя Эспера Эсперовича Ухтомского (1861-1921) - известного востоковеда, публициста, путешественника, камер-юнкера высочайшего двора в годы правления императора Николая II.

Интеллектуальное наследие Ухтомского, включавшее в себя изданные в конце XIX - начале XX вв. научные книги и статьи, публицистические работы, поэтические произведения и различного рода корреспонденцию, отражало особую систему ценностей, получившую в исследовательской литературе название “восточничество”. За последние десять лет по данной проблематике были защищены две кандидатские диссертации. ${ }^{2}$ Биография, общественнополитические взгляды и научное творчество князя Э.Э. Ухтомского также стали предметом рассмотрения в самых различных ракурсах. Геополитическому содержанию мировоззренческих установок “восточников" и князя в частности посвящены работы К.А. Медведева, В.В. Суворова и А.В. Репникова. ${ }^{3}$ Этот аспект в рамках настоящей тематики является наиболее изученным. Нельзя не отметить работы вышеупомянутых А.В. Репникова и В.В. Суворова, а также статью А.В. Ремнёва, освещающие интеллектуальный контекст эпохи и затрагивающие проблемы формирования мировоззрения “восточничества”. 4 Среди актуальных музееведческих работ выделим статьи Ю.И. Елихиной и М.В. Фёдоровой, рассматривающих роль Э.Э. Ухтомского в формировании буддийских коллекций Государственного Эрмитажа и Российского этнографического музея. ${ }^{5}$ Публицистическая и редакторская деятельность князя стала предметом исследования в работах Суня Чжинцзина и Е.Н. Крыловой. ${ }^{6}$ В историкогенеалогическом ракурсе фигура Э.Э. Ухтомского и его семьи исследовалась в статье О.Н. Наумова. ${ }^{7}$

В этой связи актуализируется цель данной статьи - рассмотреть мировоззрение одного из основоположников “восточничества" с иного концептуального ракурса, опираясь на недостаточно изученные архивные материалы, отложившиеся в результате всесторонней деятельности князя. Его

2 V.V. Suvorov, Knyaz' E.E. Uhtomskiy: zhizn', deyatel'nost', ideynoe nasledie, avtoref. diss. kand. ist. nauk (Saratov, 2011); Y.N. Strizhak, Problemy dialoga kul'tur v mirovozzrenii E.E. Uhtomskogo, avtoref. diss. kand. filosof. nauk (SPb., 2013).

${ }^{3}$ K.A. Medvedev, "Vostochnichestvo" E.E. Uhtomskogo: osnovy formirovaniya geopoliticheskoy kontseptsii”. Vestnik RGGU. Seriya: Politologiya. Istoriya. Mezhdunarodnye otnosheniya 4/14 (2018): 106-118; V.V. Suvorov, "Samoderzhavie i strategiya mirnogo rasshireniya Rossii v Azii v kontseptsii "vostochnichestva". Vlast' 11 (2015): 115-118; A.V. Repnikov, "Ne budem my zaschischat' grud'yu Evropu ot Azii" (geopoliticheskie proekty russkih konservatorov)". II Romanovskie chteniya. Tsentr i provintsiya v sisteme rossiyskoy gosudarstvennosti: materialy konferentsii. Kostroma (2009): 275-290.

${ }^{4}$ A.V. Repnikov, Konservativnye modeli Rossiyskoy gosudarstvennosti (M.: ROSSPEN, 2014); V.V. Suvorov, "Vostochnichestvo" E.E. Uhtomskogo i istoricheskaya pamyat'", Elektronniy nauchno-obrazovatel'niy zhurnal "Istoriya" 9/1 (2012): 9-10; A.V. Remnev, “Krest i mech'. Vladimir Solov'ev i Vil'gel'm II v kontekste rossiyskogo imperskogo orientalizma", Evropa 4 (2004): 56-78.

5 Y.I. Elikhina, "Tibetskaya kollektsiya Gosudarstvennogo Ermitazha". Strany i narody Vostoka XXXV (2014): 95-116; M.V. Fedorova, "Buddiyskie kollektsii v vystavochnyh proektah Rossiyskogo etnograficheskogo muzeya", Muzey. Traditsii. Etnichnost' 1/9 (2017): 61-79.

6 Sun' Chzhintsin, Kitayskaya politika v russkoy publitsistike kontsa XIX - nachala XX veka: "zheltaya opasnost"” $i$ "osobaya missiya" Rossii na Vostoke (M.: Natalis, 2008); E.N. Krylova, "Formirovanie obschestvennogo mneniya o vlasti v Rossii v nachale XX v. na primere gazety “Sankt-Peterburgskie vedomosti”. Istoriya povsednevnosti 1/1 (2016): 153162.

7 O.N. Naumov, “Knyaz'ya Uhtomskie v XX veke”, Genealogicheskiy vestnik 5 (2001): 51-58. 
Концепты “колониализм" и “антиколониализм" в оценках интеллектуального наследия князя Э.Э. Ухтомского (1861-1921)

документальное наследие обладает огромным потенциалом для междисциплинарных исследований не только в области истории и философии, но также является актуальным для религиоведов, филологов и представителей прочих направлений гуманитаристики.

Архивный фонд князя Э.Э. Ухтомского рассредоточен по нескольким архивохранилищам. Большая часть документальных материалов хранится в его личном фонде в Российском государственном историческом архиве. Этот комплекс имеет интересную судьбу: после революционных событий 1917 г. он оказался в ГАФКЭ (сейчас - РГАДА) и постепенно был там разобран. Возможно, рукописи известного петербургского востоковеда оказались в Москве по той причине, что его сын Дий Эсперович Ухтомский (1886-1918) после ранения на юго-западном фронте оказался в госпитале в Москве вместе с семьёй. Вероятно, князь Э.Э. Ухтомский переслал их невестке в Москву для передачи в архив. В 1941 г. его личный фонд был передан в ЦГИАМ (сейчас - ЦГА г. Москвы), а оттуда в 1962 г. - в ЦГИАЛ (сейчас - РГИА). В данном фонде хранится 645 дел. Также существенная часть рукописного наследия (266 дел) находится на хранении в Рукописном отделе Пушкинского дома (ф. 314).

Уже в раннем детстве князь питал интерес к истории и религии, судя по сохранившимся письменным источникам. В рукописной тетради стихотворений, которые он написал в 1876-1877 гг. (в возрасте 14-15 лет), есть произведения, общий смысл которых сводится к большому сочувствию к иным культурам и попыткам понять их изнутри. Например, в поэме “Князь Маргер” юный Эспер Ухтомский (под псевдонимом Э.У) 8 явно сочувствует литовским язычникам в деле сопротивления христианизации со стороны крестоносцев: “Не раз крестоносцы свой меч обнажали, / Чтоб силой литовский народ окрестить; / Как сёла сжигали, людей полоняли / Не мог ни один то литвин позабыть. / Борьба началась: за родные поляны, / За веру, семью и родительский кров / Народ ополчился, литовские грани / Готовились встретить отчайно врагов". 9 Многие юношеские стихотворения были проникнуты рыцарским романтизмом, в рамках которого культивировалось представление о таинственных чужеземных странах, их людях и природных ландшафтах. ${ }^{10}$ Довольно опрометчиво искать конкретные текстологические влияния на сознание формирующейся личности, но не отметить подобный интерес, имевшийся уже в раннем возрасте, невозможно.

Также следует упомянуть о существовании довольно прочного "мифа морского путешествия”, бытовавшего в семейном кругу Ухтомских. Отец будущего учёного - Эспер Алексеевич - военно-морской офицер, наиболее известный как адъютант великого князя Константина Николаевича. Нельзя забывать и о том, что Э.А. Ухтомский находился в офицерском составе фрегата “Аскольд”, который в

\footnotetext{
8 Вероятно, это один из первых зафиксированных на письме вариантов псевдонима “Э.У.”. Cм.: I.F. Masanov, Slovar' psevdonimov russkih pisateley, uchyonyh i obshchestvennyh deyateley, T. IV (M.: Iz-vo Vsesoyuznoy knizhnoy palaty, 1960): 483.

${ }_{9}^{9}$ Rossiyskiy gosudarstvenniy istoricheskiy arhiv, f. 1072, op. 1, d. 2 (1876-1877): 29 ob.

${ }^{10}$ Rossiyskiy gosudarstvenniy istoricheskiy arhiv, f. 1072, op. 1, d. 2 (1877): 26.
} 
1857-1860 гг. совершил кругосветное путешествие под командованием И.С. Унковского, и даже оставил после себя подробный дневник плавания за 1857-1858 гг., который Эспер Эсперович считал семейной реликвией и хранил в своём архиве. ${ }^{11}$ Мама будущего востоковеда - Дженни (Евгения) Алексеевна происходила из знатной морской фамилии шотландского происхождения и была родной правнучкой героя Чесменского сражения 1770 г. адмирала Самуила Карловича Грейга. Память о предке со стороны матери не могла обходить стороной ребёнка, воспитывавшегося в семье морского офицера. “Миф морского путешествия", как представляется автору, серьёзно повлиял на становление и формирование у юноши интереса к неизведанному, далёкому - иными словами, “другому". 12 Это влияние прослеживается как в раннем творчестве князя, так и в тексте сочинения “Путешествие на Восток...", где романтизируется сам процесс мореплавания: “Эскадра снимается с якоря. Морской воздух бодрящею струёй вливается в грудь. Как-то шире вокруг, как-то дышится свободнее и сильнее"13. Такие текстологические влияния не единичны и прослеживаются по всему тексту в виде коротких суждений, наподобие "худощавые туземные гребцы быстрыми вёсельными взмахами бороздят реку". ${ }^{14}$

Поступив после окончания гимназии на Историко-филологический факультет, Э.Э. Ухтомский знакомится с философом В.С. Соловьёвым - сначала как с необычным преподавателем, а уже после как с представителем оригинальной интеллектуальной традиции. Несмотря на определённые достижения и общую предрасположенность к преподаванию в области философии, выпускника Ухтомского ждала чиновничья должность в Департаменте духовных дел иностранных исповеданий МВД, в рамках которой он совершил командировки в Восточную Сибирь с целью подробного изучения буддийских (преимущественно ламаитских) общин. Глобальная задача, поставленная руководством - определить причину, по которой христианская миссия на данных территориях не имела большого успеха. ${ }^{15}$ Именно с первых командировок середины 1880-х гг. появляется профессиональный интерес Э.Э. Ухтомского к буддизму и, как следствие, к Азии как таковой.

\section{1) “Восточничество”: границы колониального и антиколониального}

C точки зрения существования общего имперского колониального представления о “другом" деятельность Э.Э. Ухтомского невозможно рассматривать вне процессов институционального мышления. Будучи прикреплённым к Департаменту духовных дел иностранных исповеданий МВД

${ }^{11}$ Rossiyskiy gosudarstvenniy istoricheskiy arhiv, f. 1072, op. 1, d. 1 (1857-1858)

12 Схожая идея о влиянии отца-моряка выражается в монографии канадского историка Дэвида Схиммельпеннинка ван дер Ойе. См.: D. Skhimmel'pennink van der Oye, Navstrechu voskhodyashchemu solntsu. Kak imperskoe mifotvorchestvo privelo Rossiyu k voyne s Yaponiey (M.: Novoe literaturnoe obozrenie, 2009 ): 168.

13 E.E. Uhtomskiy, Puteshestvie na Vostok ego imperatorskogo vysochestva gosudarya naslednika tsesarevicha. 1890 1891 (SPb.-Leyptsig: F.A. Brokgauz, 1893): 53.

14 Uhtomskiy, Puteshestvie na Vostok ego imperatorskogo vysochestva gosudarya naslednika tsesarevicha. 1890-1891, 202.

15 Rossiyskiy gosudarstvenniy istoricheskiy arhiv, f. 821, op. 10, d. 1090 (1886-1887): 3, 26-27 ob. 
Концепты “колониализм" и “антиколониализм" в оценках интеллектуального наследия князя Э.Э. Ухтомского (1861-1921)

после окончания Санкт-Петербургского университета, молодой чиновник выполнял частные задачи общеимперского содержания по исследованию буддийских (ламаитских) общин в Восточной Сибири.

Существенная часть архивных материалов его личного фонда может быть использована не только как источник для реконструирования биографии Э.Э. Ухтомского, но и в рамках изучения общественно-политической обстановки, сложившейся в обществе к концу XIX - началу XX вв., и в частности, формирования особого типа политико-философского мировоззрения, именуемого в историографии термином “восточничество”. Его происхождение остаётся невыясненным, однако, с уверенностью можно утверждать, что современники не вводили данное слово в оборот. В дореволюционных академических словарях (Энциклопедический словарь Брокгауза и Эфрона, Энциклопедический словарь Гранат, Русский биографический словарь) мы не встречаем упоминаний данного термина в рамках биографических сведений о князе, а в советских и современных изданиях подобного типа (Большая советская энциклопедия, Краткая литературная энциклопедия, Большая российская энциклопедия) статьи об Э.Э. Ухтомском и вовсе отсутствуют. Автор диссертационного исследования, посвящённого биографии Э.Э. Ухтомского, В.В. Суворов в своих работах также не даёт пространных сведений относительно происхождения данного термина. 16

Сложно с определённостью сказать, чем для общественно-политической мысли рассматриваемого периода было “восточничество”. Петербургская исследовательница Ю.Н. Стрижак полагает, что оно являлось началом большой геополитической концепции евразийства, поэтому считает возможным заменить данный термин синонимичным по значению термином “протоевразийство”. 17 Автор же рассматривает “восточничество” как некий эстетический феномен, границы которого невозможно определить с точностью, поскольку они распространялись на азиатскую культуру, религию, иной тип политического мышления-то, что кардинально отличалось по структуре от европейских эпистем. Данная эстетическая парадигма не ограничивались лишь одной областью знания о Востоке.

Всеобщая мода на “азиатчину" (эмоционально-окрашенный термин В.С. Соловьёва - A.A.) выходила далеко за рамки больших геополитических идей - она проникала в поэзию, медицину, стиль интерьеров и т.д. Появление известного всему аристократическому Петербургу тибетского лекаря Петра Бадмаева при дворе в начале XX в. было отнюдь не случайным, равно как и не была случайной мода на азиатские интерьеры. В своих воспоминаниях однокурсник Э.Э. Ухтомского по университету и крёстный отец его сына князь С.М. Волконский описывает квартиру Эспера Эсперовича: “Его квартира на Шпалерной [точный адрес: Шпалерная, 26 - A.A.] походила на какой-то храм: занавески, идолы, драконы, бронза, яшма, нефрит, лак; в аквариуме крокодил. Все это могло бы быть смешно,

${ }^{16}$ V.V. Suvorov, "Mesto "Vostochnichestva" v Rossiyskoy obshchestvennoy mysli". Vlast'12 (2012): 79.

17 Y.N. Strizhak, "Vostochnichestvo kn. E.E. Ukhtomskogo". Vestnik LGU im. A.S. Pushkina 4 (2012): 50. 
но вокруг нашего "Ухтомчика" это была наивная сказка, а для посещавших его восточных людей это была близкая им родная действительность. Китайцы, тибетцы, сиамцы, индусы и наши буряты - все являлись к нему на поклон”.18

Вместе с историографической модой на антиколониальную концепцию Эдварда Саида с особым подчёркиванием конструируемости понятий “запад” и “восток”, критика колониального дискурса получила новую точку отсчёта в виде постколониальной теории. ${ }^{19}$ В этом смысле любой исследователь-востоковед, являющийся носителем позитивистской методологии, вне зависимости от декларируемых им суждений и обоснованности выводов его исследований, автоматически причисляется к “ориенталистам”. В контексте постколониальной мысли научная и публицистическая деятельность Э.Э. Ухтомского, отстаивавшего идеи самобытности Востока как культурного и цивилизационного центра, его попытки выйти за пределы европоцентристского представления о Востоке, попытка интеллектуально синтезировать Россию и Азию с мечтами об их общем политическом пространстве - будут рассматриваться как деятельность институционального ориенталиста. ${ }^{20}$

В рамках дискурсивных практик, возникающих в разные периоды в историографии, исследователи по-разному трактуют термины “колониализм" и “антиколониализм" и используют их в разных контекстах. По этой причине автор считает необходимым объяснить, какое значение он вкладывает в данные понятия. Прежде всего, колониализм - культурный концепт, рассматривающийся вне жёсткой ретроспективной привязки и подчёркивающий неравнозначность этносоциальных, этнополитических, религиозных субъектов по отношению друг к другу. Антиколониализм - интеллектуальное течение, оппозиционный колониализму термин, подчёркивающий отсутствие любого неравенства между вышеперечисленными субъектами и выражающийся в стремлении преодолеть социальные предубеждения, основанные на идее превосходства одних этносов, народов, наций над другими.

В данном случае следует отметить, что деятельность князя Э.Э. Ухтомского с точки зрения этой дихотомии была противоречива уже в конце XIX - начале XX вв., поскольку многие современники воспринимали огромный интерес к восточным культурам, и главное - к буддизму, как некую аристократическую забаву, интеллектуальную игру и чудачество. Близкий приятель князя С.М. Волконский не воспринимал всерьёз его “восточничество”. Одним из характерных примеров “чудачеств” Волконский считал содержание в квартире на Шпалерной живого крокодила. И в этом смысле важно подчеркнуть, что он смотрел на феномен “восточничества” эстетически, не признавая его влияния на интеллектуальную жизнь императорского двора, несмотря на то, что до начала 1900-х гг., оно

${ }^{18}$ S.M. Volkonskiy, Moi vospominaniya, t. 2 (M.: Iskusstvo, 1992): 70-71.

19 E.W. Said, Orientalizm. Zapadnye koncepcii Vostoka (SPb.: Russkij mir, 2006): 12.

${ }^{20}$ Said, Orientalizm, 363. 
очевидно прослеживалось. 21 С этим влиянием даже пытались бороться как политически (обер-прокурор Святейшего Синода К.П. Победоносцев не приветствовал востокофильскую деятельность Э.Э. Ухтомского и в целом весьма негативно относился к его фигуре) ${ }^{22}$, так и публицистически - князь подвергался постоянным нападкам со стороны правоконсервативной печати. ${ }^{23}$

Существенным остаётся вопрос, можно ли сторонников схожих востокофильских взглядов считать группой в отсутствие организационной структуры, которая их объединяла. Тем не менее, типологически схожих взглядов придерживались и Сергей Фёдорович Ольденбург (1863-1934), и Пётр Александрович Бадмаев (?-1920). Если о первом лишь только ходили слухи, что тибетские буддисты почитают его за бодхисаттву, то второй стал самым ярким символом и отголоском “восточничества" императорского двора начала ХХ в., подчёркивая очевидное эстетическое тяготение высшего общества к азиатской экзотике. ${ }^{24}$ П.А. Бадмаев пытался лоббировать собственные интересы перед государем в том числе и через Григория Распутина, которого обучил тибетской методике остановки внутренних и внешних кровотечений наследника с помощью приёма порошков. 25

Не стоит забывать и о том, что концепт “колониализм" сам по себе ризоматичен и не имеет сущностной формы. В этом смысле та политическая и культурная интеграция Российской империи с цивилизациями Азии в рамках теории Э.Э. Ухтомского является лишь одной из форм интеллектуального геополитического брожения в эпоху модерна. В рамках геополитики как отдельного направления мысли появлялись разные, подчас противоположные по смыслу течения.

Трёхтомное издание "Путешествие на Восток его императорского высочества государя наследника цесаревича. 1890-1891”, благодаря которому Э.Э. Ухтомский стал известен общественности, была выполнено фактически по заказу императорского дома, поэтому выстраивать оценочные суждения лишь на основании официального нарратива невозможно. Вместе с тем, несмотря на торжественный пафос издания, мы находим в нём пространные сведения об этнорелигиозной жизни народов, населяющих ту или иную территорию, посещённую свитой будущего императора Николая II. На 230 страницах первого тома сочинения слово “белый” используется 8 раз, из них - только единожды в колониальном контексте “белый царь” (“Смуглый, полунагой, забитый, удивлённый народ, толпами сбегающий посмотреть на невиданного высокого

\footnotetext{
21 Y.N. Strizhak, "Problemy vlasti i politiki v vozzreniyah kn. E.E. Ukhtomskogo", Rozenbergovskiy sbornik: Vostokovednye issledovaniya i materialy (SPb.: Izd-vo A. Goloda, 2014): 379-380.

${ }^{22}$ Rossiyskiy gosudarstvenniy istoricheskiy arhiv, f. 1574, op. 2, d. 244 (1897-1905): 20-21.

${ }^{23}$ Skhimmel'pennink van der Oye, Navstrechu voskhodyashchemu solntsu. Kak imperskoe mifotvorchestvo privelo Rossiyu $k$ vojne s Yaponiey, 210-211.

${ }^{24}$ A.I. Andreev, Hram Buddy v Severnoy stolitse (SPb.: Nartang, 2004): 85; I.V. Lukoyanov, "Vostochnaya politika Rossii i P.A. Badmaev", Voprosy istorii 4 (2001): 120.

${ }^{25}$ Gosudarstvennyy arhiv Rossiyskoy Federatsii, f. 713, op. 1, d. 2 (1912): 1; Gosudarstvennyy arhiv Rossiyskoy Federatsii, f. 713, op. 1, d. 9 (1916): 1.
} 
гостя, который, как им сказали, приехал сюда с волшебного, непонятного, но могущественного Севера, где правит белый царь"). ${ }^{26}$ Во всех остальных случаях смысловое наполнение слова строилось вокруг описания цветов тех или иных предметов. Термином “народ” Э.Э. Ухтомский практически всегда пользовался при описании примитивных сообществ.

Черновой вариант издания подлежал предварительной “цензуре” со стороны цесаревича и будущего императора, о чём свидетельствуют его резолюции на отдельных оттисках издания. “Одобряю. Есть очень хорошие места!", “Отлично. Прочёл с живым интересом", “Хорошо” - такого рода пометы государь оставлял в тех местах, которые ему показались любопытными. Как правило, его интересовали талантливо изложенные этнографические сведения с примесью личных впечатлений за авторством Ухтомского. ${ }^{27}$

Симптоматичным является и то, что впоследствии князь Ухтомский считал необходимым советоваться с Николаем II по вопросам публикаций, значит, он считал своё мировоззрение важным с государственной точки зрения. В письме императору от 23 января 1899 г. князь писал: "Вчера я, по приглашению его [британского публициста Уильяма Томаса Стеда - A.A.], начал для его нового журнала прилагаемую статью “К вопросу о Китае”..., но остановился, чтобы продолжить её только в лучах вашего одобрения...”. ${ }^{28}$ Резолюция свидетельствует об определённом взаимопонимании: “Можете, конечно, напечатать эту статью, с каждым словом которой я вполне согласен. Приму вас в четверг в 6 часов вечера”. ${ }^{29}$

Таким образом, мы видим что границы “колониального" и “антиколониального" в текстах Э.Э. Ухтомского весьма подвижны. Являясь духовным борцом за сближение России и Азии, князь всё же находился в зависимости от имперских предубеждений колониального порядка (то, что ранее упомянутый канадский историк Дэвид Схиммельпеннинк ван дер Ойе назовёт “имперским мифотворчеством" в заглавии своей монографии). Этноконфессиональная универсальность как основное положение антиколониальных теорий, в отличие от религиозной и культурной незыблемости народов, к началу XX в. не сформировалась как топос в методологическом инструментарии интеллектуальных течений, затрагивавших актуальный во все времена вопрос “Запад или Восток?". Этим могут быть объяснены и некие “смысловые ямы” в творчестве князя Э.Э. Ухтомского.

\section{Заключение}

Исследуя мировоззренческие основы “восточников” и самого князя Э.Э. Ухтомского, невозможно феноменологически доверять источникам, транслирующим антиколониальный дискурс. Иногда исключения из правил

${ }^{26}$ E.E. Uhtomskiy, Puteshestvie na Vostok ego imperatorskogo vysochestva gosudarya naslednika tsesarevicha, 18901891 (SPb.-Leyptsig: F.A. Brokgauz, 1893): 9.

${ }^{27}$ Rossiyskiy gosudarstvenniy istoricheskiy arhiv, f. 1072, op. 2, d. 13 (1895): 1, 8; Rossiyskiy gosudarstvenniy istoricheskiy arhiv, f. 1072, op. 2, d. 14 (1892): 1.

${ }^{28}$ Rossiyskiy gosudarstvenniy istoricheskiy arhiv, f. 1072, op. 2, d. 6 (1899): 5-5 ob.

${ }^{29}$ Rossiyskiy gosudarstvenniy istoricheskiy arhiv, f. 1072, op. 2, d. 6 (1899): 5. 
лишний раз подтверждают правило - в случае с феноменом "восточничества" это работает именно так. Колониальное и антиколониальное в интеллектуальном наследии князя Э.Э. Ухтомского витиевато переплетены. Во-первых, сложно представить рождение такого масштабного по замыслу и противоречивости проекта в умах неподготовленных людей с недостаточно глубоким образованием просто потому, что большинство интеллектуальных "ревизий" совершаются аристократами (вспомним биографии большинства теоретиков революционной борьбы конца XIX - начала XX вв. в России или теоретиков постмодернизма во Франции 1960-1970-х гг.). Во-вторых, институциональность мышления большинства имперских востоковедов и их подготовка в связи с конкретными практическими задачами строительства и поддержания порядка в полиэтническом и полирелигиозном пространстве империи также не должна сбрасываться со счетов, даже когда мы говорим о концептуальном научном творчестве Э.Э. Ухтомского. Он начинал как специалист по буддизму на службе империи, поэтому вне зависимости от транслируемых им положений проблемы “Ухтомский и буддизм”, “Ухтомский и Восток”, “Ухтомский и император” обладают явным потенциалом к односторонней интерпретации. Однако, заметим, что интерес к Востоку в конечном счёте приобрел исключительно практическую значимость. В-третьих, мы говорим об интеллектуальной модели "восточничества" в эпоху раннего политического модерна, когда мир ещё не успел стать массовым, но уже стремительно пытался развиваться в эту сторону Мировоззрение "восточников" во многом отражает проблему массовости и элитарности идей, и мы предполагаем, что концепции Э.Э. Ухтомского было суждено остаться исключительно элитарной, а транслируемый в сочинениях антиколониализм не мог претендовать на идейную гегемонию в общественном сознании.

Данная статья является лишь шагом в исследовании подходов к творчеству Э.Э. Ухтомского. Задача исследователей - на основании вводимых в научный оборот архивных материалов и многочисленных текстов князя многогранно рассмотреть интеллектуальные контексты формирования "восточничества" и его разнообразные интерпретации как в рамках общественно-политической жизни конца XIX - начала XX вв., так и в современной историографии и публицистике.

\section{Beyanname:}

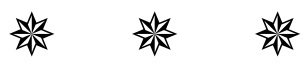

1. Etik Kurul İzni: Etik Kurul İzni gerekmemektedir.

2. Katkı Oranı Beyanı: Yazar, makaleye başkasının katkıda bulunmadığını beyan etmektedir.

3. Çıkar Çatışması Beyanı: Yazar, herhangi bir çıkar çatışması olmadığını beyan etmektedir.

\section{Declarations:}

1. Ethics approval: Not applicable. 
2. Author contribution: The author declares no one has contributed to the article.

3. Competing interests: The author declares no competing interests.

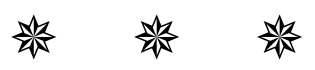

\section{СПИСОК ИСТОЧНИКОВ И ЛИТЕРАТУРЫ (ВIBLIOGRAРНY)}

\section{Архивные материалы (Archival materials)}

Gosudarstvennyy arhiv Rossiyskoy Federatsii, f. 713, op. 1, d. 2 (1912).

Gosudarstvennyy arhiv Rossiyskoy Federatsii, f. 713, op. 1, d. 9 (1916).

Rossiyskiy gosudarstvenniy istoricheskiy arhiv, f. 1072, op. 1, d. 2 (1876-1877).

Rossiyskiy gosudarstvenniy istoricheskiy arhiv, f. 1072, op. 1, d. 1 (1857-1858).

Rossiyskiy gosudarstvenniy istoricheskiy arhiv, f. 1072, op. 2, d. 13 (1895).

Rossiyskiy gosudarstvenniy istoricheskiy arhiv, f. 1072, op. 2, d. 14 (1892).

Rossiyskiy gosudarstvenniy istoricheskiy arhiv, f. 1072, op. 2, d. 6 (1899).

Rossiyskiy gosudarstvenniy istoricheskiy arhiv, f. 1574, op. 2, d. 244 (1897-1905).

Rossiyskiy gosudarstvenniy istoricheskiy arhiv, f. 821, op. 10, d. 1090 (1886-1887).

\section{Опубликованные источники (Published sources)}

Uhtomskiy E.E. Puteshestvie na Vostok ego imperatorskogo vysochestva gosudarya naslednika tsesarevicha. 1890-1891. SPb.-Leyptsig: F.A. Brokgauz, 1893.

Volkonskiy S.M. Moi vospominaniya, t. 2. M.: Iskusstvo, 1992.

\section{Литература (Books and Articles)}

Andreev, A.I. Hram Buddy v Severnoy stolitse. SPb.: Nartang, 2004.

Chzhintsin, Sun'. Kitayskaya politika v russkoy publitsistike kontsa XIX - nachala XX veka: "zheltaya opasnost" $i$ "osobaya missiya" Rossii na Vostoke. M.: Natalis, 2008.

Elikhina, Y.I. "Tibetskaya kollektsiya Gosudarstvennogo Ermitazha". Strany i narody Vostoka XXXV (2014): 95-116.

Fedorova, M.V. "Buddiyskie kollektsii $\mathrm{v}$ vystavochnyh proektah Rossiyskogo etnograficheskogo muzeya". Muzey. Traditsii. Etnichnost' 1/9 (2017): 61-79.

Krylova, E.N. "Formirovanie obschestvennogo mneniya o vlasti v Rossii v nachale XX v. na primere gazety "Sankt-Peterburgskie vedomosti". Istoriya povsednevnosti 1/1 (2016): 153-162.

Lukoyanov, I.V. "Vostochnaya politika Rossii i P.A. Badmaev". Voprosy istorii 4 (2001): 111-126.

Masanov, I.F. Slovar' psevdonimov russkih pisateley, uchyonyh i obshchestvennyh deyateley. T. IV. M.: Iz-vo Vsesoyuznoy knizhnoy palaty, 1960.

Medvedev, K.A. "Vostochnichestvo" E.E. Uhtomskogo: osnovy formirovaniya geopoliticheskoy kontseptsii". Vestnik RGGU. Seriya: Politologiya. Istoriya. Mezhdunarodnye otnosheniya 4/14 (2018): 106-118.

Naumov, O.V. “Knyaz'ya Uhtomskie v XX veke”, Genealogicheskiy vestnik 5 (2001): 51-58. 
Концепты “колониализм” и “антиколониализм” в оценках интеллектуального наследия князя Э.Э. Ухтомского (1861-1921)

Remnev, A.V. “'Krest i mech'. Vladimir Solov'ev i Vil'gel'm II v kontekste rossiyskogo imperskogo orientalizma". Evropa 4 (2004): 56-78.

Repina, L.P. "Intellektual'naya istoriya na rubezhe XX-XXI vekov". Novaya i noveyshaya istoriya, № 1 (2006): 12-22.

Repnikov, A.V. Konservativnye modeli Rossiyskoy gosudarstvennosti. M.: ROSSPEN, 2014.

Repnikov, A.V. "Ne budem my zaschischat' grud'yu Evropu ot Azii" (geopoliticheskie proekty russkih konservatorov)". II Romanovskie chteniya. Tsentr i provintsiya $v$ sisteme rossiyskoy gosudarstvennosti: materialy konferentsii. Kostroma (2009): 275290.

Said, E.W. Orientalizm. Zapadnye koncepcii Vostoka. SPb.: Russkij mir, 2006.

Skhimmel'pennink van der Oye D., Navstrechu voskhodyashchemu solncu. Kak imperskoe mifotvorchestvo privelo Rossiyu $k$ vojne $s$ Yaponiey. M.: Novoe literaturnoe obozrenie, 2009.

Strizhak, Y.N. "Problemy vlasti i politiki v vozzreniyah kn. E.E. Ukhtomskogo". Rozenbergovskiy sbornik: Vostokovednye issledovaniya i materialy (SPb.: Izd-vo A. Goloda, 2014): 377-394.

Strizhak, Y.N. "Vostochnichestvo kn. E.E. Ukhtomskogo". Vestnik LGU im. A.S. Pushkina 4 (2012): 50-58.

Strizhak, Y.N. Problemy dialoga kul'tur v mirovozzrenii E.E. Uhtomskogo, avtoref. diss. kand. filosof. nauk. SPb., 2013.

Suvorov, V.V. "Mesto "Vostochnichestva" v Rossiyskoy obshchestvennoy mysli". Vlast' 12 (2012): 78-80.

Suvorov, V.V. "Samoderzhavie i strategiya mirnogo rasshireniya Rossii v Azii v kontseptsii "vostochnichestva". Vlast'11 (2015): 115-118.

Suvorov, V.V. "Vostochnichestvo" E.E. Uhtomskogo i istoricheskaya pamyat"', Elektronnyy nauchno-obrazovatel'nyy zhurnal "Istoriya" 9/1 (2012): 9-10.

Suvorov, V.V. Knyaz' E.E. Uhtomskiy: zhizn', deyatel'nost', ideynoe nasledie, avtoref. diss. kand. ist. nauk, Saratov, 2011. 